\title{
Şanlıurfa' da kadın sağlık çalışanlarının doğurganlık özellikleri ve doğurganlığa bakış açıları
}

\author{
Fatma Koruk ${ }^{1}$, İbrahim Koruk², Özlem Güner ${ }^{3}$, Sibel Ayhan³ ${ }^{3}$, Ayşegül Kılıçlı ${ }^{3}$, Sidar \\ Aytekin ${ }^{3}$, Deniz Utku Altun'.
}

\begin{abstract}
${ }^{1}$ Harran Üniversitesi. S. B. F. Doğum ve Kadın Hastalıkları Hemşireliği AD., Şanlıurfa ${ }^{2}$ Harran Üniversitesi Tıp Fakültesi Halk Sağlığı Anabilim Dalı, Şanlıurfa ${ }^{3}$ Harran Üniversitesi Sağlık Bilimleri Enstitüsü Hemșirelik Anabilim Dalı, Şanlıurfa 4Şanlıurfa Halk Sağlı̆̆ı Müdürlüğü, Şanlıurfa
\end{abstract}

Öz

Amaç: Çalışma, Şanlıurfa'da kadın sağlık çalışanlarının doğurganlık özelliklerini ve doğurganlığa bakış açılarını belirlenmek amacıyla yapılmıştır. Yöntem: Araştırma kesitsel tiptedir. Örnek seçiminde küme örnekleme yöntemi kullanılmıştır. Örnekleme 174 kadın sağlık çalışanı alınmıștır. Araştırmanın verileri yüz yüze görüşme tekniği ile Kasım-Aralık 2014 tarihleri arasında toplanmıştır. Bulgular: Kadın sağlık çalışanlarının yaş ortalaması $33.2 \pm 6.2$ 'dir. Calıșanların \%72.4'ü ebe/hemșire, \%14.4'ü hekim, \%13.2'si teknisyendir. Kadınların ilk evlilik yaş ortalaması $24.4 \pm 2.8$, ilk gebelik yaş ortalaması $25.6 \pm 3.2$, gebelik sayısı ortalaması $2.0 \pm 1.0$ ve yaşayan çocuk sayısı ortalaması $1.6 \pm 0.8$ 'dır. Gebeliği önleyici modern yöntem kullanımı \%72.3'tür. En sık yöntem kullanmama nedeni çocuk istemidir. Lojistik regresyon modeline göre; 3 ve üzeri gebelik sayısı kadın sağlık çalışanlarında 35 yaş ve üstü olanlarda 6.0 kat, eşi esnaf olanlarda 3.9 kat daha fazladır. Sonuç: Kadın sağlık çalışanları doğurganlıkları ile ilgili karar verme sürecinde etkindirler. Gebelik kontrolleri oldukça yüksektir ancak zaman zaman başarısızlıklar da yaşanmaktadır.

Anahtar kelimeler: Kadın, sağlık çalışanı, üreme sağlığı

Yazının geliş tarihi: 04.07.2017

Yazının kabul tarihi: 02.10.2017

Sorumlu Yazar: Yrd. Doç. Dr. Fatma Koruk Harran Üniversitesi Sağlık Bilimleri Fakültesi Osmanbey Kampüsü merkezi derslikler binası 2. Kat Haliliye / Şanlıurfa

Telefon: (542) $7240212 \quad$ Fax: (414) 3183203 E Posta: fgozukara18@gmail.com

Not: Bu çalışma, 9-11 Nisan 2015 tarihleri arasında Adana'da 1. Uluslararası Çukurova Kadın Çalışmaları Kongresinde bildiri olarak sunulmuştur. 


\title{
Fertility features and perspectives of female healthcare workers in Şanlıurfa
}

\begin{abstract}
Aim: The study was conducted to determine the fertility features and perspectives of the female healthcare workers in Şanlıurfa. Method: This was a cross-sectional study. Cluster sampling method was used. 174 female healthcare workers were included in the study. Research data was collected through a formed survey in face-to-face interviews between November and December 2014. Results: Mean age of the workers was 33.2 \pm 6.2 . Among the all, $72.4 \%$ of the workers were midwives, $14.4 \%$ of physicians and $13.2 \%$ of technicians. While the average of age at first marriage was $24.4 \pm 2.8$, the average of age at first pregnancy was $25.6 \pm 3.2$. Average number of pregnancies was $2.0 \pm 1.0$ and living children was $1.6 \pm 0.8$. The rate of using modern contraceptive methods was found $72.3 \%$. The most common reason preferring not to use such methods was the desire to have a child. According to logistic regression model, the rates of women having 3 or more pregnancies are 6.0 and 3.9 fold higher among those aged 35 and over, among those whose husbands are tradesmen, respectively. Conclusion: Female healthcare workers are effective in the decision-taking process related to fertility. Pregnancy controls are highly frequent but failures are experienced occasionally.
\end{abstract}

Key words: Woman, healthcare workers, and reproductive health

\section{Giriş}

Sağlık çalışanı kadınlarda üreme sağlığı ve doğurganlığı, annelik ve kadınlık ideolojisinin şekillendirdiği cinsiyetler arasındaki farklılıklara ilișkin kültürel ön kabuller ve inançlar ${ }^{1}$, bir sağlı profesyoneli olarak sahip olduğu bilgiye paralel olarak aldığı tutum ve davranışları ${ }^{2}$ ile iş yaşamında maruz kaldıkları ortam faktörleri $^{3}$ gibi farklı yönleri olan bir konudur.

Türkiye'de sağllk ve sosyal hizmet işlerinde istihdam edilen kadınlar, toplam kadın istihdamının \%7.3'ünü oluşturmaktadır. Bu işlerde istihdam edilen kadın sayısı 2012 yılında 505 bin iken 2013 yılında 558 bine yükselmiştir. Başka bir ifade ile bu sektörde kadın istihdamı 2013 yılında \%65.0'e yükselmiştir. Genellikle işgücünün yarısı, hatta yarısından fazlasının kadınlardan oluşmasıyla özdeşleştirilmiş bir olgu olan işgücünün feminizasyonu sağlık sektörü için de söz konusu edilmektedir. 4 Sağlık sektöründe kadın sayısının fazla olmasında hemşirelik ve ebelik mesleklerinin geleneksel olarak kadın işi kabul edilmesinin önemli bir payı vardır.5Pek çok ülkede hemşirelerin \%90'dan fazlası kadındır ve hekimler arasında da kadınların düzeyinin giderek arttığı gözlenmektedir.6Kadınların, sağlık sektöründe profesyonel meslek mensupları olarak bu yoğunlukta istihdam edilmelerinin tesadüf olmadı̆ $\breve{l}$, Cumhuriyetin ilk dönemlerinde kurucu kadroların yönünü batılılaşmaya dönerek liberal, demokratik ve laik bir toplum yaratma hedeflerine paralel olarak kadınları hem modern Cumhuriyetin simgeleştiği bedenler hem de Cumhuriyetin gelișen sanayi ve bürokrasinin ihtiyaç duyduğu işgücü olarak görüldüğü belirtilmektedir.7 Buna paralel olarak, sağlık çalışanlarından mesleki sorumlulukları ve sosyal rolleri gereği tutum ve davranışları ile de hizmet verdikleri grubu etkilemeleri beklenmektedir.,8,9 Toplumda lider konumunda olan kadın sağlık çalışanları, sundukları doğru bilgi ve uygulamalarıyla sağlıkla ilgili olumlu davranışlar kazandırmakta ve davranış değişikliklerini motive etmekte büyük katkı sağlamaktadır. ${ }^{10}$ Ancak, hizmet verenlerin kendi kişisel eğilimleri nedeniyle kadınların üreme sağlığı programlarından yararlanmalarına engel oluşturdukları da bilinmektedir.11

Toplumsal cinsiyet eşitsizliğinin etkisiyle kadınlar daha az öğrenim görmekte 
daha az işgücüne katılmakta ve daha az gelir elde etmektedir. Toplumsal cinsiyet eşitsizliği sağlık alanında kadının en çok üreme sağlığını etkilemektedir. Bu yönüyle bakıldığında, artan eğitimin doğurganlıkla ilgili süreçleri belirlemede etkili olduğu, özellikle sağlık eğitimi almış kadınlarda gebeliklerin planlı ve gebelik risklerinin daha iyi kontrol altında tutulması beklenmektedir. ${ }^{12}$

Bu çalışma Şanlıurfa ilinde çalışan kadın sağlık çalışanlarının doğurganlık özelliklerini ve doğurganlığa bakış açılarını belirlenmek amacıyla yapılmıștır.

\section{Gereç ve yöntem}

Araştırmanın tipi:Araștırma kesitsel tiptedir ve 2014 yılı Kasım-Aralık ayları arasında yürütülmüștür.

Araştırmanın evreni ve örneklem seçimi: Araştırmanın evrenini, Şanlıurfa Kamu Hastaneleri Birliği Genel Sekreterliği'ne bağlı il merkezindeki dört hastanedeki $(\mathrm{N}=935)$ ve Harran Üniversitesi Araştırma ve Uygulama Hastanesindeki ( $\mathrm{N}=194)$ doktor, hemşire, ebe, acil tıp teknisyeni, diyetisyen, eczacl, fizyoterapist, sağlık teknisyeni olan 1129 evli kadın sağlık çalışanı oluşturmuştur.

Örnek seçiminde küme örnekleme yöntemi kullanılmıștır. Personel listelerindeki oluşan hızlı değișiklikler nedeniyle bu örnekleme yöntemi tercih edilmiştir.

İl merkezindeki kamu hastaneleri ve HÜAUH' sinde toplam 67 branș polikliniği, 52 yataklı servis, 22 radyoloji ünitesi, 18 laboratuvar, 17 yoğun bakım ünitesi(YBÜ), sekiz Elektro ensefalografi (EEG)-Elektro miyografi (EMG) odası, altı acil servis, beș sterilizasyon ünitesi, beş kan merkezi, dört diyaliz ünitesi, dört ameliyathane,üç fizik tedavi ünitesi, üç kemoterapi ünitesi, iki doğumhane, iki endoskopi odası, iki sintigrafi ünitesi, iki taş kırma (ESWL) odası ve bir yanık ünitesi bulunmaktadır. Her bir ünite bir küme olarak kabul edilmiştir. Toplam 223 küme bulunmaktadır. Her bir ünitede çalışan sağlık çalışanı küme birimi olarak alınmıştır. Küme çapları (her bir ünite çalışan kişi sayısı) sürekli değiştiği ve güncel bilgiye ulaşılamadığı için HÜAUH'nde iki yoğun bakım, iki servis, iki poliklinik, bir nükleer tıp ünitesi, bir kan merkezi, bir yoğun bakım ünitesi, bir endoskopi ünitesi olmak üzere toplam 10 kümenin dahil edildiği pilot çalışma yapılmıştır. Pilot çalışmada evrenin ilgi duyulan bağımlı değişkeni olarak gebelik sayısı alınmıştır. Pilot uygulamadan elde edilen ortalama küme çapı 2.80, gebelik sayısı ortalaması 1.25 , tahmini varyans 1.43 , hata tahmin sınırı 0.15 olarak alınarak, gerekli küme büyüklüğü 40 olarak hesaplanmıştır. Kümeler ünite tipine ve hastanelerdeki küme sayılarına göre tabakalandırma yapıldıktan sonra rastgele yöntemle seçilmiştir.Seçilen kümelerde ziyaret yapılan günde iş yerinde bulunan personel araştırmaya dahil edilmiştir. Toplamda 174 kadın sağlık çalışanı araştırmaya katılmıștır.

\section{Verilerin}

toplanması:Verilerin toplanmasında yapılandırılmış bir anket kullanılmıştır. Anket, sağlık çalışanlarına verilerek kendilerinin doldurmaları istenmiştir. Anket, sağlık çalışanlarının sosyo-demografik özelliklerini (yaş, doğum yeri, öğrenim durumu, meslek, çalışma süresi, çalışılan birim, eşinin eğitim durumu, sosyal sınıflar, kronik hastalık durumu vb) ve doğurganlık özelliklerini (ilk evlenme ve gebelik yaşı, gebelik sayısı, doğum sayısı, aralığı, çocuk sayısl, düşük/kürtaj/ölü doğum yapma durumu ve sayısı, aile planlaması yöntemlerine ilișkin özellikleri), doğurganlığa bakış açılarını (ideal evlenme yaşı, ideal ilk ve son gebelik yaşı, ideal çocuk sayısı, ideal doğum șekli) içermektedir.

Eşin mesleği sınıflaması için Prof. Dr. Korkut Boratav'ın kentsel ve kırsal sosyal sınıf şeması kullanılmıştır. ${ }^{13}$

Calışmanın sinırlılıkları: Örneklem sayısı hesaplamada gebelik sayısı kullanılmıştır. Ülkemizde gebelikler büyük oranda evlilik içerisinde gerçekleştiği için örnekleme ulaşma kolaylığından dolayı çalışma sadece evli kadınlarla yapılmıştır. Çalışmaya sadece evli sağlık çalışanlarının dahil edilmesi çalışmanın sınırlılığıdır. 
Araştırmanın etik boyutu:Araştırmanın uygulanabilmesi için Harran Üniversitesi Tıp Fakültesi Etik Kurulu'ndan 12.12.2014 tarih ve 02 sayılı alınmıştır. Araştırmaya katılmayı kabul eden kadınlar araștırmaya dahil edilmiştir.

Verilerin değerlendirilmesi: Araştırmadan elde edilen veriler bilgisayar ortaminda Statistical Package for Social Sciences (SPSS) for Windows 20.0 istatistik paket programı kullanılarak analiz edilmiştir. Verilerin değerlendirilmesinde tanımlayıcı istatistikler, ki kare testi, çok değişkenli değerlendirme için lojistik regresyon analizi kullanılmıştır.

Araștırmanın bağımlı değişkeni gebelik sayısıdır. Tek değişkenli analizlerde ve lojistik regresyon analizinde gebelik sayısı 2 ve altı/ 3 ve üzeri olarak kategorik hale getirilmiştir. 3 kesme noktası, analizlerde yeterli sayıyı sağlamak için tercih edilmiştir.

Lojistik regresyon analizi için, bağımsız değiş̧kenlerden yaş(35 yaş altı/35 yaş ve üstü), doğum yeri( Güneydoğu Anadolu Bölgesi/ diğer), eş eğitim durumu (lise/ lise üstü), kronik hastalık durumu (var/yok), eşinin mesleği(esnaf/diğer) modele alınmıştır. Lojistik regresyon analizinde backward stepwise conditional yöntemi kullanılmıştır.

\section{Bulgular}

Çalışmaya katılan kadın sağlık çalışanlarının yaş ortalaması $33.2 \pm 6.2$ 'dir. Çalışma süresi ortalaması $11.1 \pm 6.6$ yıl olup, Şanlıurfa'da çalışma süresi ortalaması

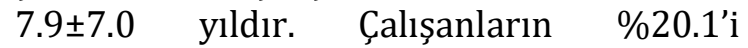
poliklinikte, \%40.2'si serviste, \%12.6'sı yoğun bakımda, \%5.2'si ameliyathanede, \%16.1'i laboratuvarda ve \%5.7'si tanı ve tedavi ünitelerinde çalışmaktadır.

Çalışanların yaklaşık yarısının doğum yeri Güneydoğu Anadolu Bölgesi illerinden birisidir. Çalışanların, \%98.3'ü kent merkezinde yaşamaktadır, \%62.6'sı lisans ve üstü düzeyde eğitim almıştır, \%72.4'ü ebe-hemşiredir. Katılımcıların \%65.0'inin eşi lisans ve üstü düzeyde eğitim almıştır. Eşlerinin \%23.0'ü yüksek nitelikli ücretli/kendi hesabına çalışan grubundadır. \%16.7'sinin her hangi bir kronik hastalığ vardır (Tablo 1).

Çalışmada kadın sağlık çalışanlarının ilk evlilik yaş ortalaması $24.4 \pm 2.8$, ilk gebelik yaş ortalaması $25.6 \pm 3.2$, gebelik sayısı ortalaması $2.0 \pm 1.0$ ve yaşayan çocuk sayısı ortalaması $1.6 \pm 0.8$ olarak belirlenmiştir (Tablo 2).

Tablo 1. Kadın sağlık çalışanlarının bazı sosyo-demografik özelliklerinin dağılımı

\begin{tabular}{|c|c|c|}
\hline $\begin{array}{l}\text { Sosyo-Demografik } \\
\text { Özellikler }\end{array}$ & Sayı & $\%$ \\
\hline \multicolumn{3}{|l|}{ Doğum yeri } \\
\hline Güneydoğu & 83 & 47.7 \\
\hline \multicolumn{3}{|l|}{ Anadolu Bölgesi } \\
\hline Diğer bölgeler & 91 & 52.3 \\
\hline \multicolumn{3}{|l|}{$\begin{array}{l}\text { Son } 5 \text { yıldır en uzun } \\
\text { yașanan yer }\end{array}$} \\
\hline İlçe & 3 & 1.7 \\
\hline İl merkezi & 171 & 98.3 \\
\hline \multicolumn{3}{|l|}{ Eğitim Durumu } \\
\hline Lise & 18 & 10.3 \\
\hline Ön lisans & 47 & 27.0 \\
\hline Lisans & 79 & 45.4 \\
\hline Lisansüstü & 30 & 17.2 \\
\hline \multicolumn{3}{|l|}{ Mesleği } \\
\hline Doktor & 25 & 14.4 \\
\hline Ebe-Hemşire & 126 & 72.4 \\
\hline Teknisyen & 23 & 13.2 \\
\hline \multicolumn{3}{|l|}{ Eșin eğitim durumu } \\
\hline İlkokul & 1 & 0.6 \\
\hline Lise & 25 & 14.4 \\
\hline Ön lisans & 35 & 20.1 \\
\hline Lisans & 77 & 44.3 \\
\hline Lisansüstü & 36 & 20.7 \\
\hline \multicolumn{3}{|l|}{ Esin mesleği } \\
\hline $\begin{array}{l}\text { Yüksek nitelikli } \\
\text { ücretli/kendi } \\
\text { hesabına çalıșan }\end{array}$ & 40 & 23.0 \\
\hline $\begin{array}{l}\text { Beyaz yakalı/mavi } \\
\text { yakalı işçi }\end{array}$ & 115 & 66.1 \\
\hline Esnaf & 19 & 10.9 \\
\hline \multicolumn{3}{|l|}{$\begin{array}{l}\text { Kronik hastalığa sahip } \\
\text { olma durumu }\end{array}$} \\
\hline Evet & 29 & 16.7 \\
\hline Hayır & 145 & 83.3 \\
\hline TOPLAM & 174 & 100.0 \\
\hline
\end{tabular}


Tablo 2. Kadın sağlık çalışanlarının ilk evlilik yaşı, ilk gebelik yaşı, gebelik sayısı, yaşayan çocuksayısı düzeyleri

\begin{tabular}{lcc}
\hline Özellikler & $\begin{array}{c}\text { Ortalama - } \\
\text { standart } \\
\text { sapma }\end{array}$ & $\begin{array}{c}\text { Ortanca } \\
\text { (Min-Mak) }\end{array}$ \\
\hline İlk evlilik yaşı & $24.4 \pm 2.8$ & $24(18-35)$ \\
İlk gebelik yaşı & $25.6 \pm 3.2$ & $25(15-36)$ \\
Gebelik sayısı & $2.0 \pm 1.0$ & $2(1-6)$ \\
Yaşayan çocuk & $1.6 \pm 0.8$ & $2(0-4)$ \\
sayısı & & \\
\hline
\end{tabular}

Tablo 3'de kadın sağlık çalışanlarının bazı doğurganlık özelliklerinin dağılımı verilmiştir. Kadınların \%23.6'sının en az bir kez düșük, \%4.0'nün en az bir kez kürtaj, \%2.9'nun en az bir kez ölü doğum, \%20.1'nin plansız/istemeden gebelik ve \%10.9'nun iki yıldan daha kısa aralarla doğum öyküsü olduğu belirlenmiștir.

Kadın çalışanların \%99.4'ü sahip olacakları çocuk sayısına kendi ya da eşi ile birlikte kendisi karar vermektedir. \%2.3'ü cinsiyet tercihinden dolayı doğum yapmaktadır.

Tablo 4'de kadın sağlık çalışanlarının kullandığı gebeliği önleyici yöntem özelliklerinin dağılımı verilmiștir. Kadınların \%25.9'nun gebeliği önleyici yöntem kullanmadığı, gebeliği önleyici yöntem kullananların ise sırası ile en fazla kondom (\%29.3), RİA (\%28.7) ve OKS (\%12.6) kullandığı belirlenmiștir. Herhangi bir gebeliği önleyici yöntem kullanmayan kadın sağlık çalışanları, yöntem kullanmama nedeni olarak en fazla gebe olmalarını ve gebe kalmak istemelerini ifade etmişlerdir.

Tablo 5'de kadın sağlık çalışanlarının doğurganlığa bakış açılarına ilişkin bazı özelliklerin düzeyi verilmiştir. Kadınların bildirdiği, ideal ilk evlilik yaş ortalaması $24.5 \pm 2.2$ yıl, ideal çocuk sayısı ortalaması $2.8 \pm 0.9$, ideal ilk gebelik yaş ortalaması $25.2 \pm 2.1$ yıl, ideal son gebelik yaş ortalaması $34.3 \pm 2.8$ yıl, ideal iki gebelik arasındaki süre ortalaması $3.2 \pm 1.1$ yıl, bir kadının az riskli olarak doğurabileceği en fazla çocuk sayısı ortalaması 3.4 \pm 0.8 'tür.

Kadın sağlık çalışanlarının \%93.7'si ideal doğum şeklinin normal vajinal doğum olduğunu belirtmektedir.

Çalışanların ilk evlilik yaşı $24.4 \pm 2.8$ ve kendi bildirimi ideal evlilik yaşı ortalaması $24.5 \pm 2.2$ olarak saptanmıştır. Ölçümler arasında grup içi korelasyon katsayısı 0.36 (\%95 Güven Aralığı (GA)= 0.14-0.52) olarak saptanmıștır. Ölçümler arasında orta düzeyde tutarlılık vardır.

Tablo 3. Kadın sağlık çalışanlarının bazı doğurganlık özelliklerinin dağılımı

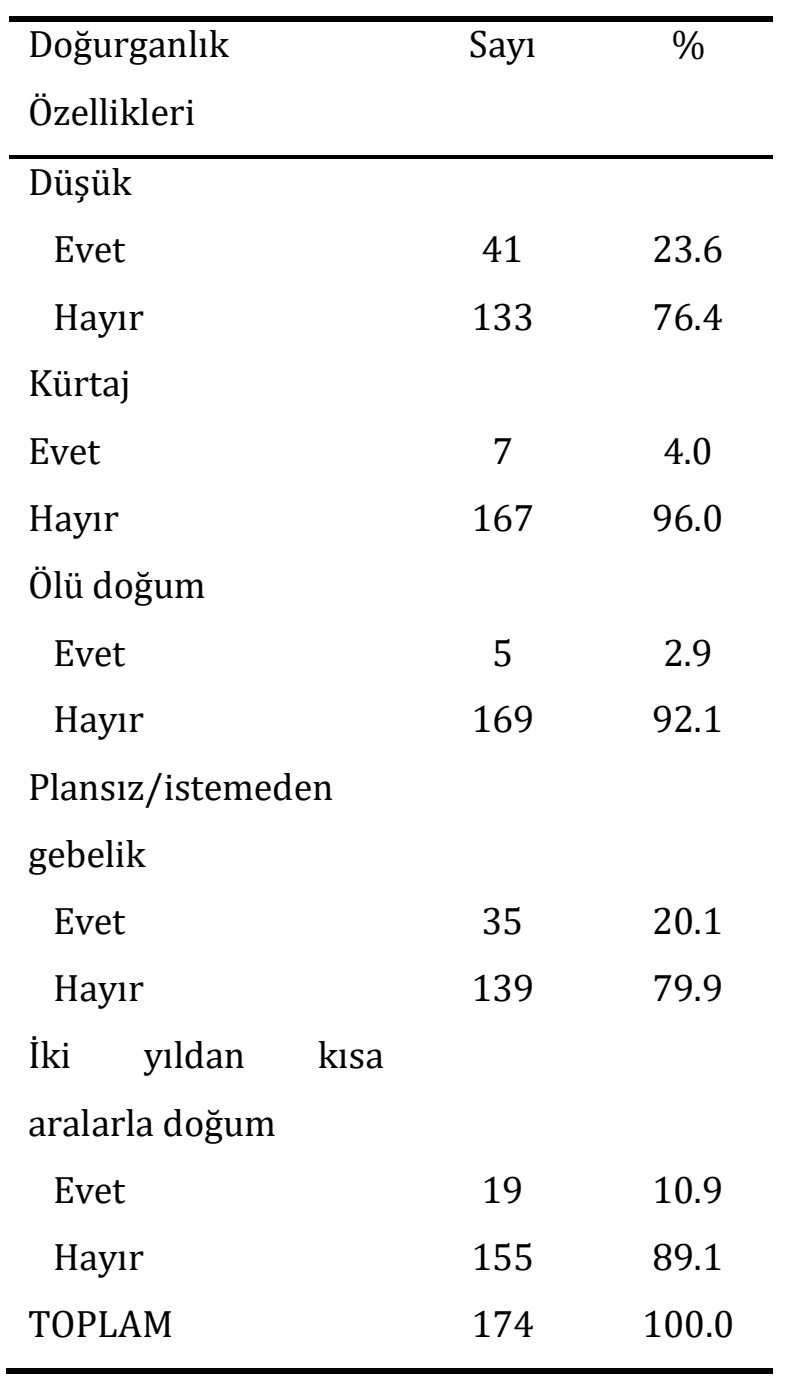


Tablo 4. Kadın sağlık çalışanlarının kullandığı gebeliği önleyici yöntem özelliklerinin dağılımı

\begin{tabular}{lcc}
\hline Yöntem & Sayı & $\%$ \\
\hline Modern Yöntem & 126 & 72.3 \\
OKS & 22 & 12.6 \\
Kondom & 51 & 29.3 \\
RİA & 50 & 28.7 \\
Tüp ligasyon & 3 & 1.7 \\
Geleneksel Yöntem & 3 & 1.8 \\
Takvim yöntemi & 1 & 0.6 \\
Geri çekme & 1 & 0.6 \\
Laktasyonelamenore & 1 & 0.6 \\
Yöntem Kullanmiyor & 45 & 25.9 \\
Menapozda & 4 & 2.3 \\
Şu anda gebe & 21 & 12.1 \\
Gebe kalmak istiyor & 17 & 9.8 \\
Yan etkiler & 3 & 1.7 \\
TOPLAM & 174 & 100.0 \\
\hline
\end{tabular}

Çalışanların ilk gebelik yaşı ortalaması $25.6 \pm 3.2$ ve kendi bildirimi ideal gebelik yaşı ortalaması 25.2 \pm 2.1 olarak saptanmıştır. Ölçümler arasında grup içi korelasyon katsayısı 0.50 (\%95 GA= 0.330.63) olarak saptanmıştır. Ölçümler arasında iyi düzeyde tutarlılık vardır.

Kadın sağlık çalışanlarının bazı özelliklerinin gebelik sayısına etkisi incelendiğinde; 3 ve üstünde gebelik geçirme, doğum yeri Güneydoğu Anadolu Bölgesi'nde olanlarda(\%36.1), eşinin mesleği esnaf olanlarda(\%57.9), kronik hastalı̆̆l olanlarda (\%44.8), eșinin eğitim düzeyi lise olanlarda(\%33.3) daha fazladır $(p<0.05)$. Kadın sağlık çalışanın eğitim durumu, mesleği ve ilk evlilik yaşının gebelik sayısına etkisi saptanmamıștır (p>0.05) (Tablo 6).

Gebelik sayısıüzerine bağımsız değişkenlerin etkisinin birlikte değerlendirildiği lojistik regresyon analiz sonuçları Tablo 7'de gösterilmiştir. Lojistik regresyon modeline göre; kadın sağlık çalışanlarında 3 ve üzeri gebelik sayısı 35 yaş ve üstü olanlarda 6.0 kat, eşi esnaf olanlarda 3.9 kat daha fazladır (Tablo 7).

Tablo 5. Kadın sağlık çalışanlarının doğurganlığa bakış açılarına ilişkin bazı özelliklerin düzeyi

Özellikler

Ortalama \pm standart sapma

Ortanca (Min-Mak)

İdeal ilk evlilik yaşı

$24.5 \pm 2.2$

25 (18-30)

İdeal çocuk sayısı

$2.8 \pm 0.9$

$3(1-5)$

İdeal ilk gebelik yaşı

$25.2 \pm 2.1$

$25(20-30)$

İdeal son gebelik yaşı

$34.3 \pm 2.8$

$35(25-44)$

İdeal iki gebelik arasındaki süre

$3.2 \pm 1.1$

$3(2-10)$

En az riskle doğurulabilecek en

fazla çocuk sayısı

$3.4-0.8$

$4(1-6)$ 
Tablo 6. Çalışanların bazı sosyo-demografik ve doğurganlık özelliklerinin gebelik sayısına göre dağılımı

\begin{tabular}{|c|c|c|c|c|c|c|}
\hline \multirow[b]{3}{*}{ Özellikler } & \multicolumn{4}{|c|}{ Gebelik Sayısı } & \multirow[b]{3}{*}{$\chi^{2}$} & \multirow[b]{3}{*}{$\mathrm{p}$} \\
\hline & \multicolumn{2}{|c|}{2 ve altı } & \multicolumn{2}{|c|}{3 ve üstü } & & \\
\hline & Sayı & $\%^{*}$ & Sayı & $\% *$ & & \\
\hline \multicolumn{7}{|l|}{ Yaşı } \\
\hline 34 yaș ve altı & 82 & 88.2 & 11 & 11.8 & \multirow[t]{2}{*}{23.1} & \multirow[t]{2}{*}{$<0.001$} \\
\hline 35 yas ve üstü & 44 & 54.3 & 37 & 45.7 & & \\
\hline \multicolumn{7}{|l|}{ İlk Evlilik Yaşı } \\
\hline 20 yaş ve altı & 5 & 45.5 & 6 & 54.5 & \multirow[t]{2}{*}{$* * *$} & \multirow[t]{2}{*}{0.073} \\
\hline 21 yaş ve üstü & 121 & 74.2 & 42 & 25.8 & & \\
\hline \multicolumn{7}{|l|}{ Mesleği } \\
\hline Doktor & 21 & 84.0 & 4 & 16.0 & \multirow[t]{3}{*}{2.1} & \multirow[t]{3}{*}{0.34} \\
\hline Ebe - Hemșire & 88 & 30.2 & 38 & 69.8 & & \\
\hline Teknisyen & 17 & 73.9 & 6 & 26.1 & & \\
\hline \multicolumn{7}{|l|}{ Eğitim Durumu } \\
\hline Lise & 12 & 66.7 & 6 & 33.3 & \multirow[t]{4}{*}{2.5} & \multirow[t]{4}{*}{0.47} \\
\hline Ön lisans & 32 & 68.1 & 15 & 31.9 & & \\
\hline Lisans & 57 & 72.2 & 22 & 27.8 & & \\
\hline Lisansüstü & 25 & 83.3 & 5 & 16.7 & & \\
\hline \multicolumn{7}{|l|}{ Doğum Yeri } \\
\hline Güneydoğu Anadolu Bölgesinde & 53 & 63.9 & 30 & 36.1 & \multirow[t]{2}{*}{5.0} & \multirow[t]{2}{*}{0.02} \\
\hline Diğer bölgelerde & 73 & 80.2 & 18 & 19.8 & & \\
\hline \multicolumn{7}{|l|}{ Kronik Hastalığa Sahip Olma Durumu } \\
\hline Evet & 16 & 55.2 & 13 & 44.8 & \multirow[t]{2}{*}{4.1} & \multirow[t]{2}{*}{0.04} \\
\hline Hayır & 110 & 75.9 & 35 & 24.1 & & \\
\hline \multicolumn{7}{|l|}{ Eşin Mesleği } \\
\hline Yüksek nitelikli ücretli/kendi hesabına & 28 & 70.0 & 12 & 30.0 & \multirow[t]{3}{*}{10.8} & \multirow[t]{3}{*}{0.004} \\
\hline Beyaz yakalı/mavi yakalı işçi & 90 & 78.3 & 25 & 21.7 & & \\
\hline Esnaf* $^{* *}$ & 8 & 42.1 & 11 & 57.9 & & \\
\hline \multicolumn{7}{|l|}{ Eşinin Eğitim Durumu } \\
\hline Lise $^{* *}$ & 14 & 53.8 & 12 & 46.2 & \multirow[t]{4}{*}{8.2} & 0.04 \\
\hline Ön lisans & 24 & 68.6 & 11 & 31.4 & & \\
\hline Lisans & 57 & 74.0 & 20 & 26.0 & & \\
\hline Lisansüstü & 31 & 86.1 & 5 & 13.9 & & \\
\hline
\end{tabular}

*Satır yüzdesi, ** Fark yaratan grup ${ }^{* * *}$ Fisher Kesin Ki Kare testi

Tablo 7. Kadın sağlık çalışanlarının gebelik sayısına etkisi olan değişkenlerin birlikte değerlendirildiği lojistik regresyon modeli

\begin{tabular}{lcccc}
\hline Etkileyen Faktörler & $\mathrm{B}$ & $\mathrm{p}$ & $\mathrm{OR}$ & $\% 95 \mathrm{GA}$ \\
\hline Yaş (35 yaş ve üstü) & 1.8 & $<0.001$ & 6.0 & $2.7-13.2$ \\
Eşinin mesleği (esnaf) & 1.3 & 0.012 & 3.9 & $1.36-11.7$ \\
Sabit & -2.1 & $<0.001$ & & \\
\hline
\end{tabular}




\section{Tartışma}

Araştırmaya katılanların çoğunluğu genç çalışanlardan oluşmaktadır. Eşleri genellikle yüksek eğitim düzeyindedir. Eşinin mesleğine göre çoğunluğu orta/üst sosyal sinıftadır ve kent merkezinde yaşamaktadır. Yarıya yakını doğum yeri olarak Güney Doğu Anadolu illerinden birisini belirtmiştir.

Çalışanların meslekte de yeni oldukları söylenebilir. Şanlıurfa'da yapılan bir araştırmada bu çalışmadaki sonuçlara benzer şekilde sağlık çalışanlarının çoğunluğunun meslekte geçirdikleri sürenin ve Şanlıurfa'daki çalışma süresinin çok fazla olmadığı, bunun bölgedeki personel hareketliliğinden kaynaklandığı belirtilmektedir. ${ }^{14}$

Şanlıurfa'daki kadın sağlık çalışanlarının büyük bir kısmı Türkiye'deki kadın sağlık çalışanı dağılımına paralel olarak ebe-hemşireler oluşturmaktadır. Çoğu servislerde ve polikliniklerde çalışmaktadır. ${ }^{14}$ Sağlık sektörünün ihtiyaç duyduğu sağlık profesyoneli talebine paralel olarak çalışan kadınların da eğitim düzeyinin yüksek olması beklenen bir durumdur.

İlk evlenme yaşının küçük olduğu toplumlar genellikle erken çocuk sahibi olan ve doğurganlığı yüksek olan toplumlardır. ${ }^{15}$ Kadın sağlık çalışanlarının ilk evlenme yaşı ve ilk gebelik yaşı, TNSA 2013'de de belirtilen tüm kadınların evlilik ortancası olan 21 yıl ve ilk gebelik ortancası 22.9 yıldan daha yüksektir.16Canbaz ve $\operatorname{arkadaşları}^{2} \mathrm{da}$ kadın sağlık çalışanlarında ilk evlilik ve ilk gebelik yaşını toplumdan daha yüksek olarak belirtmektedir. $\mathrm{Bu}$ sonuçlarda, kadın sağlık çalışanlarının ergenlik ve gençliklerindeki önemli bir süreyi eğitimlerini sürdürerek geçirmelerinin ve bu süreç içinde aldıkları eğitimin yaşamlarında yarattığ değişikliklerin önemli bir katkısı vardır. Nitekim, araştırmalar, eğitimsiz kadınların daha erken yaşlarda evlendiğini ve buna bağlı olarak doğurganlığın erken yaşta başladığını ortaya koymaktadır. ${ }^{16}$

$\mathrm{Bu}$ araştırmanın sonuçlarına benzer olarak, Öztürk'ün ${ }^{17} A f y o n ' d a \quad$ yaptığı çalışmada ortalama gebelik sayısı $1.7 \pm 1.1$ ve ortalama yaşayan çocuk sayısı $1.3 \pm 0.8$ olarak belirtilirken; Dündar'ın'18Samsun'da yaptığı çalışmada evli ebelerde ortalama gebelik sayısı $2.1 \pm 0.9$, ortalama yaşayan çocuk sayısı ise $1.8 \pm 0.6$ olarak belirtmektedir. TNSA 2013'de ise halen evli kadınlarda yaşayan ortalama çocuk sayısı 2.2 olarak belirtilmektedir. ${ }^{16} \mathrm{Bu}$ sonuçlar ışığında, sağlık çalışanı kadınların Türkiye'deki evli kadınlardan daha az çocuk sahibi oldukları ve gebeliklerinin sonucunda çocukların çoğunun hayatta kaldığı söylenebilir. Kadınların yüksek düzeyde eğitimli ve sağlık profesyoneli olması, doğurganlık kontrollerinin yüksek olması göz önünde bulundurulduğunda bu beklenen bir sonuçtur. Başka bir araştırmada,bu eğilimin ortaya çıkmasında, eğitimli ve geliri yüksek olan kadınların daha az doğurarak firsat maliyetlerini arttırma çabasının olduğu belirtilmektedir. ${ }^{19}$

Kendiliğinden düşük ve ölü doğumlar genellikle kadınların kendi kontrolü dışında gerçekleșen olaylardır. Özellikle kadın sağlık çalışanları üreme sağlıkları ile ilgili pek çok konuda başarılı olmalarına rağmen çalışma ortamlarından kaynaklı ve üreme sistemi üzerine olumsuz etkisi olan pek çok ortam faktörlerine de maruz kalabilmekte ve bu faktörlerin ölü doğum, düşük, düşük doğum ağırlıklı bebek ve infertilite gibi olumsuz sonuçları ile de karşılaşabilmektedir. ${ }^{3} \mathrm{Bu} \quad$ araştırmada doğrudan ortam faktörlerine yönelik bir bulgu elde edilmemiş olmakla birlikte kadın sağlık çalışanlarının doğurganlık dönemleri boyunca yaşadıkları kendiliğinden düşük ve ölü doğum düzeyi TNSA 2013'te belirtilen sırası ile \%22.8 ve \%3.3 değerlerinden çok küçük bir yükseklik göstermektedir. ${ }^{16}$

Plansız/istenmeyen gebelikler, gebeliğin isteyerek sonlandırılması ve iki yıldan kısa aralarla doğum öyküsü, çiftlerin doğurganlıklarını ne kadar başarıyla kontrol edebildiklerini gösteren önemli göstergelerdendir. $\mathrm{Bu}$ araştırmada sağlık çalışanı kadınların da toplumdaki diğer kadınlar gibi planlanmamış gebelikler yaşadıkları ve gebeliklerini isteyerek sonlandırdıkları görülmektedir. Ancak, 2013 TNSA'ya göre evli kadınların \%23.7'sinin gebeliklerini planlamadıklarını/ 
istemediklerini, \%13.5'i en az bir kez gebeliğini isteyerek sonlandırdığı göz önüne alındığında sağlık çalışanı kadınların gebeliklerini kontrol etmede daha başarılı oldukları söylenebilir. Ancak, bu hizmetleri bilen ve sunan profesyoneller olduğu göz önüne alındığında ise gebelik kontrolünde daha başarılı olmaları beklenmektedir. Bazı yazarlar tarafından isteyerek düşük düzeyinin eğitim durumu en yüksek olan kadınlarda daha fazla gözlemlendiği belirtilse de, 2013 TNSA'da eğitim durumuna göre farklılaşma olmakla birlikte isteyerek düşükler ve eğitim durumu ile ilgili belirgin bir örüntü bulunmadığ belirtilmektedir. ${ }^{16,20}$.

Öte yandan 2013 TNSA'da belirtildiği gibi toplumun \%17.5'inin de iki yıldan daha kısa aralıklı doğum öyküsü varken ${ }^{16}$ sağlık çalışanlarında doğum aralığ kontrolü daha başarılıdır. Nitekim bu araştırmada kadın sağlık çalışanlarının yaklaşık dörtte üçünün gebeliği önleyici herhangi bir modern yöntem kullandığı belirlenmiştir. Ancak, kadın sağlık çalışanlarının hem eğitim düzeyinin yüksek olması hem de konunun profesyonelleri olmaları nedeniyle hayatlarının bir döneminde gebelik kontrolünde başarısızlık yaşamış olmaları başka araştırmalarda da incelemeye değer bir durumdur.

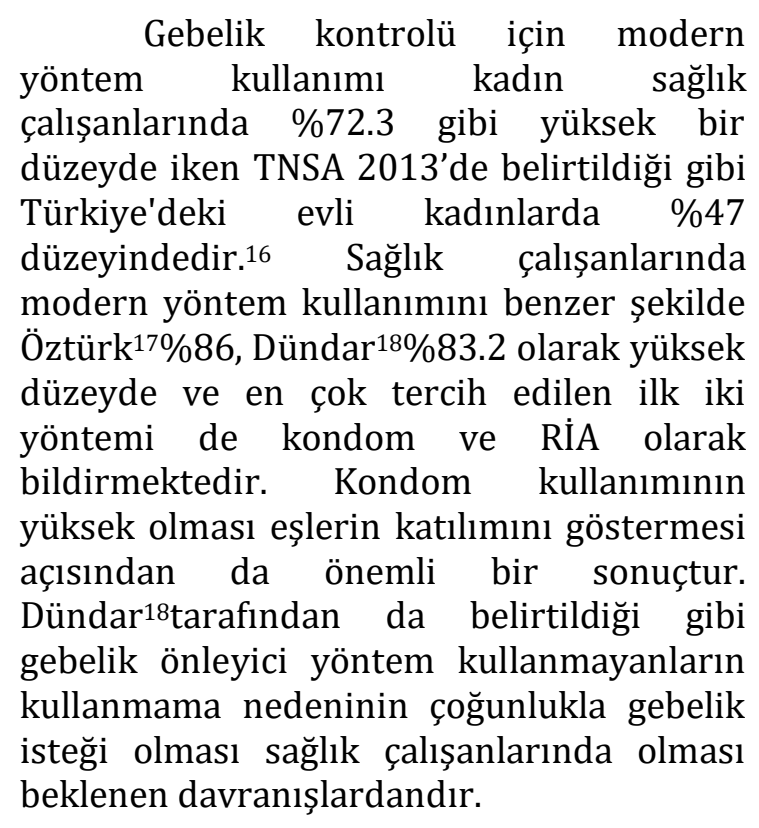

Sağlık çalışanı kadınlar sahip olacakları çocuk sayısına kendileri ya da eşi ile birlikte karar vermektedir. Cinsiyet tercihine göre doğum yapma davranışı da çok düşük düzeydedir. Kadınların eğitim düzeyinin yükselmesi, iş ve meslek sahibi olmaları karar verme sürecine katılmalarını ve toplumsal cinsiyet temelli davranışlardan da uzaklaşmalarını kolaylaştırmaktadır.

Araştırmalar, Türkiye'de kadınların bildirdiği ideal çocuk sayısının iki ile üç arasında değiştiğini göstermektedir. ${ }^{16,21,22} \mathrm{Bu}$ durum, bu araștırmanın sonuçları ile de uyumludur. Sağlık çalışanlarının yaşayan çocuk sayısının ideal çocuk sayısından düşük olması muhtemelen üreme dönemini tamamlamamış daha genç kadınların da araştırmada yer almasından kaynaklanmış olabilir. Sağlık çalışanı kadınların gebelik sayısı kadar yaşayan çocukları olması da olumlu değerlendirilmesi gereken bir sonuçtur.

Kadın sağlık çalışanlarının tamamına yakını ideal doğum şeklinin normal vajinal doğum olduğunu belirtmektedir. Yapılan pek çok araştırmada da kadınların çoğunun ideal doğum şekli olarak normal vajinal doğumu ifade ettikleri ve normal doğumu sezaryen doğuma daha üstün buldukları belirtilmektedir.23,24

Sağlık çalışanı kadınların bildirdikleri ideal ilk evlilik yaşı ve ilk gebelik yaşı ile deneyimledikleri ilk evlilik yaşı ve ilk gebelik yaşı arasında orta ya da iyi düzeyde tutarlılık olması beklenildiği gibi bu kadınların kararlarında isabetli davrandıklarına işaret etmektedir.

Genel olarak yaşla birlikte çocuk sayısının arttığı görülmektedir. Özellikle 4149 yaş aralığında daha fazla belirginleşmektedir. ${ }^{19}$

Kadınlar çocuk sahibi olma kararını büyük oranda kendileri ya da eşleri ile birlikte aldıklarını ifade etmektedirler. Ancak, eşin esnaf olması gebelik sayısını arttıran bir faktördür. Bu artan gelir ya da erkeğin eğitim düzeyi ile ilgili bir sonuç olabilir. Nitekim Selim ve Üçdoğruk ${ }^{19}$ Türkiye'deki yedi ilin verilerini kullandığı çalışmasında yukarıdaki açıklamalara uygun olarak kadının sürekli işinden elde ettiği gelirdeki artış, kadınların zaman maliyetini artırdığından çocuk sayısı ile negatif ilişkili ancak hanehalkı gelirinin 
çocuk sayısı ile pozitif ilişkili olduğu sonucuna ulaşmıştır. Yine Kutlar'da ${ }^{25}$ uzun vadede ücretle çocuk sayısı arasında pozitif ilişki olduğunu vurgulamaktadır.

\section{Sonuç ve öneriler}

Kadın sağlık çalışanları aileleri ile birlikte orta ve üst sosyal sinıftadır. İlk evlilik ve ilk gebelik yaşları ortancası riskli sınırlarda değildir. Sahip oldukları çocuk sayısı nüfus yenilenme sınırına yakındır. Beklenildiği gibi, kadın sağlık çalışanları etkili doğum kontrol yöntemleri kullanmaktadır ve gebeliği önleyici yöntem kullanmama nedenleri çoğunlukla gebe olmaları ya da gebelik istemeleri ile ilişkilidir. Küretaj, ölü doğum gibi olumsuz sonuçlarla karşılaşma durumları düşüktür. Doğurganlıkları ile kararlarında belirleyici durumdadır. Gebelik kontrolleri oldukça yüksek olmakla birlikte zaman zaman başarısızlıklar da yaşanmaktadır.Bu olumlu tabloda sağlık bilgisine sahip olmaları, yüksek eğitimli olmaları ve ekonomik olarak hayatlarını kazanabilme yeteneklerinin olması muhtemel belirleyicilerdir. Tüm kadınların bu olanaklara ulaşması hayatlarına yön vermeleri açısından gereklidir.

\section{Kaynaklar}

1. Urhan B, Etiler N. Sağlık sektöründe kadın emeğinin toplumsal cinsiyet açısından analizi. Çalışma ve Toplum 2011;2(29):191-215.

2. Canbaz S, Sünter AT, Süren C, Pekșen Y. Kadın sağlık çalışanlarının doğurganlık özellikleri, gebelik ve doğum sonu dönemdeki çalışma koşulları. Kocatepe Tıp Dergisi 2005;6(2):39-44.

3. Mesleki Güvenlik ve Sağlık Ulusal Enstitüsü. İşyeri Tehlikelerinin Kadın Üreme Sağlığına Etkileri 1999 [online]. Erişim yeri: http://www.cdc.gov/niosh/docs/99104/pdfs/99-104.pdf. Erişim tarihi: 22. 02.2016 .
4. Türkiye İstatistik Kurumu. Türkiye İstatistik Yıllığı 2013[online].Erişim yeri: http://www.tuik.gov.tr/Kitap.do?metod $=$ KitapDetay\&KT_ID=0\&KITAP_ID $=1$. Erişim tarihi: 22.02. 2016.

5. Özsoy AS, İz BF. Toplumsal yapıda hemşirelerin konumu. Toplum ve Hekim. 2005;20(4):254-258.

6. Leith LH. Why do women still earn less than men? Monthly Labour Review 2014[Online]. Erişim yeri: http://www.bls.gov/opub/mlr/2014/be yond-bls/pdf/why-do-women-still-earnless-than-men.pdf. Erişim tarihi: 24.03. 2016.

7. Bayrakçeken T. Kadın Hekimler Açısından Mesleki Kimliğin Anlamı. 2. Kadın Hekimlik ve Kadın Sağlığı Kongresi, Ankara, 2010:134-136.

8. Ayaz S, Tezcan S, Akıncı F. Hemşirelik yüksekokulu öğrencilerinin sağlı̆̆ geliştirme davranışları. Cumhuriyet Üniversitesi Hemşirelik Yüksekokulu Dergisi 2005;9(2):26-34.

9. Oran T, Turgay S. Hemşirelik öğrencilerinin sağlık davranışları. Ege Üniversitesi Hemşirelik Yüksek Okulu Dergisi 2006;22(2):281-291.

10. Alıcı S, Sarıkaya Ö. Sağlık Davranışlarının Geliştirilmesinde Yaşantılayarak öğrenme Uygulaması. Dokuz Eylül Üniversitesi Hemşirelik Yüksek Okulu Elekronik Dergisi 2009;2(3):95-101.

11. Şimşek H. Toplumsal Cinsiyet Eşitsizliğinin Kadın Üreme Sağlığına Etkisi: Türkiye Örneği. Dokuz Eylül Üniversitesi Tıp Fakültesi Dergisi 2011;25(2):119-126.

12. Akın A, Özvarış ŞB. Kadın Sağlı̆̆ı, Üreme Sağlığı ve Aile Planlaması.İçinde: Güler Ç, Akın L (Eds.): Halk Sağlı̆ı Temel Bilgiler, Genişletilmiş ikinci baskı, Ankara: Hacettepe Üniversitesi Yayınları; 2012:220-233. 
13. Boratav K. İstanbul ve Anadolu'dan Sınıf Profilleri. Ankara: İmge Kitabevi Yayınları; 2004.

14. Koruk İ, Tekin-Koruk S, Tuncer K, Demir C, Kara B, Şeyhanoğlu AS. Şanlıurfa'da Sağlık Çalışanlarının Mesleki Bulaşıcı Hastalıklara Karşı Așılanma Düzeyi. Klimik Dergisi 2014;27(2):48-56.

15. Özvarış Ș. Doğurganlığın Düzenlenmesi. Sağlık ve Toplum 1998;8(3-4):45-48.

16. Hacettepe Üniversitesi Nüfus Etütleri Enstitüsü. Türkiye Nüfus ve Sağlık Araștırması 2013. Erișim yeri: http://www.hips.hacettepe.edu.tr/tnsa2 013/rapor/TNSA_2013_ana_rapor.pdf. Erişim tarihi: 27.03. 2016.

17. Öztürk Ç. Sağlık Personelinin Aile Planlaması Yöntemlerini Tercih Nedenleri. (Yayınlanmamış Yüksek Lisans Tezi)Gülengül Köken, Afyon,2009.

18. Dündar C, Kaynar E, Pekșen Y. Samsun ili merkez sağlık ocaklarında çalıșan evli ebelerin aile planlaması yöntemi kullanma durumları. İnönü Üniversitesi Tıp Fakültesi Dergisi 2005;12(4):243246.

19. Selim S, Üçdoğruk Ş. Sayma veri modelleri ile çocuk sayısı belirleyicileri: türkiye'deki seçilmiş iller için sosyoekonomik analizler.Dokuz Eylül
Üniversitesi Íktisadi ve İdari Bilimler Fakültesi Dergisi 2003;18(2):13-31.

20. Sak ME, Evsen M, Sak S, Çaça F. Kontrasepsiyon yöntemlerinin etkinliği ve kadınların eğitim düzeyi: Güneydoğu Anadolu'da bir ilçe örneği. Dicle Tıp Dergisi 2008;35(4):265-270.

21. Altuntaş F, Madya AS. Bolu Dörtdivan İlçesi'nde aile planlaması hizmetlerinin değerlendirilmesi. Düzce Üniversitesi Sağllk Bilimleri Enstitüsü Dergisi 2011;1(1):1-7.

22. Cangöl S. Lalapaşa Merkez İlçe'de yaşayan 15-49 yaş grubu kadınların üreme sağlığı durumları. (yayınlanmamıș Yüksek Lisans Tezi), Galip Ekuklu, Edirne,2010.

23. Duman Z, NG K, Şahin K, Coșar E, Arıöz D, Aral İ. Sağlık çalışanlarının normal doğum ve sezaryen ile ilgili düşünceleri. Perinatoloji Dergisi 2007;15(1):1-7.

24. Çakmak B, Arslan S, Nacar C. Kadınların isteğe bağlı sezaryen konusundaki görüşleri.Firat Tıp Dergisi 2014;19(3):122-125.

25. Kutlar A, Erdem E, Aydın FF. Kadınların işgücüne katılması ile doğurganlık, boşanma ve ücret haddi arasındaki ilişki: Türkiye üzerine bir araştırma.Bilgi Ekonomisi ve Yönetimi Dergisi 2012;7(1):149-168. 